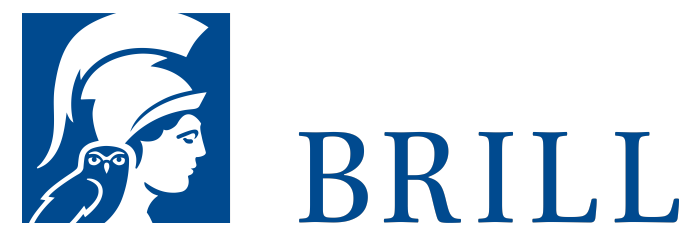

\title{
Barthes' Mythos im Rahmen konkreter Ironie
}

Literarische Konstruktionen des Eigenen und des Fremden

Author: Christoph Leitgeb

Die zentrale Hypothese: Ironie bricht Alltagsmythen, „Frames“, in denen Kulturelles natürlich erscheint. Rahmentheorie und Barthes' Mythen-begriff werden zu Bausteinen einer Theorie der Ironie, die Alternativen zur disziplinären Aufsplitterung des Ironie-begriffs und seiner inflationären Ver-wendung in der Postmoderne aufzeigen will. Das Buch entwickelt einen sprachwis-senschaftlich, kulturtheoretisch und philosophisch anschlussfähigen Ironiebegriff und überprüft seine Tragfähigkeit in der exemplarischen Analyse von literarischen Texten. In praktischen Anwendungen erprobt Leitgeb diese Perspektive: Seine Interpretationen analysieren keinen „Kanon“, sondern testen die Hypothese in Versuchsfeldern (beispielsweise Ironie in "konkreter Literatur" und Ironieverbot in der konventionaliserten Textsorten „Lebenslauf“). Das Fazit des Schlusskapitels bezieht Elemente einer traditionellen Gegenüberstellung von Ironie und Mythos noch einmal explizit auf „Frame“- Theorien.

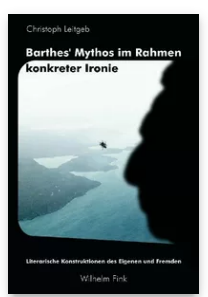

Pages: 207 Seiten, $6 \mathrm{~s} / \mathrm{w}$ Abb.

Language:

German

Subjects:

General,

Literature and

Cultural Studies

Publisher: Brill |

Fink

E-Book (PDF)

Released online: 16 Dec 2019

ISBN: $978-3^{-}$

8467-4620-2

List price

USD \$ \$8.00

Paperback

Publication date: O2 Apr 2008

ISBN: 978-3-

7705-4620-6

List price

USD \$48.00 
For more information see brill.com

Order information: Order online at brill.com +44330 333 0049 | customerservices@brill.com Submission information: brill.com/authors

Titles published by Brill | Fink, Brill | mentis or Brill | Schöningh: +49(o)715413279216| brill@brocom.de 